\section{CEO Narsisizmi Araştırmalarının Metodolojik Açıdan Sistematik İncelenmesi ve Eleştirel Değerlendirilmesi}

\author{
Halit Keskin $^{\mathrm{a}}$, Selahaddin Samil Fidan ${ }^{\mathrm{b}}$
}

Öz: Çalışma kapsamında CEO (chief executive officer) narsisizmi araştırmalarının metodoloji bölümlerinin sistematik bir şekilde incelenmesi ve eleştirel bir şekilde değerlendirilmesi amaçlanmıştır. CEO narsisizmi araştırmalarında kullanılan ölçüm araçlarının avantajlı ve dezavantajlı yönleri değerlendirilmiştir. Web of Science kapsamında taranan 55 CEO narsisizmi makalesi ülke, sektör, dergi, veri kaynakları, ölçüm araçları ve ilave geçerlilik testleri açısından sistematik bir şekilde incelenmiştir. Çalışma sonuçlarına göre, çoğunlukla Amerika Birleşik Devletleri'nde faaliyet gösteren firmalardan veri toplanarak araştırmaların gerçekleştirildiği görülmüştür. Eğitim, sağlık ve hukuk alanında herhangi bir çalışmaya rastlanılamamıştır. Küçük ve orta ölçekli firmaların CEO'larına nadiren odaklanıldığı bulunulmuştur. 55 çalışmadan 32 çalışma CEO narsisizmi indeksini kullanmaktadır. Ölçüm araçları kullanımı konusunda ortak benimsenmiş bir sürecin düşük düzeyde olduğu tespit edilmiştir. Bütün çalışmaların CEO narsisizmini genel ve değişmez bir eğilim olarak varsaydığı görülmüştür. CEO narsisizmi indeksini kullanan 32 çalışmadan sadece 10 çalışmanın ilave geçerlilik analizi testi yaptığı bulunmuştur. Üçüncü taraf değerlendirmelerini ölçüm aracı olarak kullanan 9 çalışmadan 7 çalışmanın ilave geçerlilik analizi testi yaptığı bulunmuştur. Herhangi bir nitel araştırma desenine rastlanılamamıştır.

\section{A Systematic Review and Critical Evaluation of Methodology Sections of CEO Narcissism Research}

Abstract: The aim of this study is to systematically review and critically evaluate the methodology sections of CEO (chief executive officer) narcissism research. We evaluated the advantages and disadvantages of measurement tools used in CEO narcissism research. We systematically examined 55 CEO narcissism articles scanned within the scope of Web of Science in terms of country, industry, journal, data sources, measurement tools, and additional validity tests. According to the results of the study, CEO narcissism studies were mostly carried out by collecting data from the United States companies. No study was found in the field of education, health, and law. Small and medium sized firms were rarely focused. 32 studies out of 55 studies used the CEO narcissism index. A standard process in the use of measurement tools was low. All studies have postulated CEO narcissism as a general and invariant tendency. Of the 32 studies using the CEO narcissism index, only 10 studies performed additional validity analysis. 7 studies out of 9 studies using third-party evaluations were found to perform additional validity analysis. No qualitative research design has been found.
Anahtar Sözcükler: CEO Narsisizmi, Metodoloji, Ölçüm Araçları, Geçerlilik Testleri

JEL: M10, M12, M19

$\begin{array}{ll}\text { Geliş } & : 08 \text { Ocak 2021 } \\ \text { Düzeltme } & : \text { 10 Mart 2021 } \\ \text { Kabul } & : \text { 19 Nisan 2021 } \\ \text { Tür } & : \text { Araştırma }\end{array}$

Keywords: CEO Narcissism, Methodology, Measurement Tools, Validation Tests

JEL: M10, M12, M19

$\begin{array}{ll}\text { Received } & : 08 \text { January } 2021 \\ \text { Revised } & : 10 \text { March } 2021 \\ \text { Accepted } & : \text { 19 April } 2021 \\ \text { Type } & \text { : Research }\end{array}$

a Prof., PhD., Yildiz Technical University, Faculty of Economic and Administrative Sciences, Department of Business Administration, Istanbul, Turkiye, hkeskin@yildiz.edu.tr (ORCID ID: 0000-0003-4432-3998)

b Res. Asst. Yildiz Technical University, Faculty of Economic and Administrative Sciences, Department of Business Administration, Istanbul, Turkiye, ssfidan@yildiz.edu.tr (ORCID ID: 0000-0002-7643-2139) 


\section{Giriş}

Narsisizm kavramı, bireylerin güçlü bir şekilde kendilerini haklı hissetmesi, aşırı beğenmesi, empati eksikliği, sosyal takdir gereksinimi ve üstünlük hissiyatı ile ilişkilendirilir (Fehn ve Schütz, 2020; Thielmann, Spadaro ve Balliet, 2020). Narsisizm kavramının, CEO $^{1}$ araştırmalarında gündeme gelmesi ve gelişim göstermesi Chatterjee ve Hambrick (2007) tarafından geliştirilen CEO narsisizmi indeksi sayesindedir. CEO narsisizmi indeksi, CEO narsisizmi araştırmalarında yaygın bir şekilde kullanılmaktadır (Chatterjee ve Hambrick, 2011; Patel ve Cooper, 2014; Engelen, Neumann ve Schmidt, 2016).

CEO narsisizmiyle ilgili alan yazınındaki araştırmalar CEO narsisizmi indeksi dışında farklı ölçüm araçlarından faydalanmaktadır. Bu kapsamda CEO'ların imza büyüklüğü aracılı̆ı̀la CEO'ların narsistik eğilimlerini ölçümleyen çalışmalar vardır (Ham, Lang, Seybert ve Wang, 2017; Ham, Seybert ve Wang, 2018). CEO narsisizmini geçerliliği ve güvenirliği olan Narsistik Kişilik Eğilimi Envanteri aracıllı̆ıyla doğrudan CEO'lardan veri toplayarak ölçümleyen çalışmalar da bulunmaktadır (Wales, Patel ve Lumpkin, 2013; Liu, Hao ve Zhang, 2019). Bazı çalışmalar ise, CEO'ların çeşitli ortamlarda bulunan videolarını üçüncü kısım uzmanların izlemesini sağlayarak bu uzmanlardan çeşitli ölçekler aracılığıyla CEO'ların narsistik eğiliminin değerlendirilmesini istemektedir (Petrenko, Aime, Ridge ve Hill, 2016; Gupta, Nadkarni ve Mariam, 2019). Bu bağlamda, CEO narsisizmi araştırmalarında dört temel ölçüm aracı ön plana çıkmaktadır: CEO narsisizmi indeksi, CEO imza büyüklüğü, CEO narsisizmi ölçekleri ve üçüncü kısım uzman değerlendirmeleri.

CEO narsisizmi araştırmalarını metodolojik açıdan sistematik bir şekilde inceleyen ve eleştirel bir değerlendirme sunan yeterli düzeyde çalışmaya rastlanılamaması çalışmanın temel motivasyon kaynaklarındandır. Ayrıca, CEO narsisizmi araştırmalarında birbirinden oldukça farklı narsisizmin ölçüm araçlarının kullanıldığı görülmektedir (örneğin, Ham vd., 2017; O'Reilly III, Doerr ve Chatman, 2018; AlShammari, Rasheed ve Al-Shammari, 2019). Bu farklı kullanımın ötesinde, aynı ölçüm aracının benzer çalışmalarda farklı şekillerde kullanıldığı örneklere bile rastlanılmaktadır (örneğin, Chatterjee ve Hambrick, 2007; Judd, Olsen ve Stekelberg, 2017). Bu durum, CEO narsisizmi araştırmalarına metodolojik açıdan yardımcı olacak rehber niteliğinde yeterli çalışmaya rastlanılmamasıyla birleşince, konu üzerinde yeni çalışacak araştırmacılar için CEO narsisizminin ölçüm sürecinin anlamlandırılması oldukça zorlaşmaktadır. Diğer bir karmaşık nokta, CEO narsisizmi araştırmalarında kullanılan ilave geçerlilik analizleri sürecidir. İlave geçerlilik analizleri kapsamında hangi ölçüm araçlarının nasıl kullanıldığını yeterli düzeyde aydınlatan çalışmaya rastlanılamamıştır. Bu bağlamda, çalışmanın bütüncül katkısı, CEO narsisizmi araştırmalarında kullanılan ölçüm süreçlerini bütüncül ve derinlikli bir şekilde yansıtmak, ölçüm sürecinin nasıl gerçekleştiğini açık ve net bir şekilde ortaya koymak ve benimsenmiş ortak bir ölçüm sürecinin olup olmadı̆̆ını veriye dayalı bir şekilde aydınlatmaktır. Buna ilaveten, CEO narsisizmi araştırmalarının bilimsel yolculuğunda yer almak isteyen bilim insanlarına hem gelecek ajandası oluşturulması hem de yüksek kaliteli CEO narsisizmi araştırmalarının üretilmesine yardımcı olunması temel katkı alanlarındandır.

Çalışma kapsamında, ilk olarak, CEO narsisizmi araştırmalarında yaygın olarak kullanılan farklı ölçme araçlarının, CEO'ların narsistik eğilimlerini nasıl ölçtüğü ölçüm araçlarının olumlu ve olumsuz yönleriyle birlikte değerlendirilmiştir. İkinci aşamada, CEO narsisizmi konusundaki ampirik araştırmalar sistematik bir şekilde belirlenmiştir. Belirlenen CEO narsisizmi çalışmaları ülke, sektör, dergi, veri kaynakları, ölçme araçları ve ilave geçerlilik analizi testleri açısından incelenmiştir. Bu inceleme kapsamında, CEO narsisizm araştırmalarının ortak bir ölçüm sürecine sahip olup olmadığı ve ilave ya da destekleyici geçerlilik analizlerinin yapılıp yapılmadığı özellikle aydınlatılmaya çalışıımışır. Sistematik inceleme sonrasında, CEO narsisizm araştırmalarının metodoloji bölümleriyle ilgili sonuçlar eleştirel bir süzgeçten geçirilerek gelecek araştırmalar için önerilerde bulunulmuştur. Böylece, CEO narsisizmiyle ilgili ampirik araştırmaların metodoloji bölümlerinin sistematik bir şekilde incelenmesi, eleştirel bir şekilde değerlendirilmesi ve gelecek araştırmalar için öneriler sunulması amaçlanmıştır. 


\section{CEO Narsisizminin Temel Ölçüm Araçları}

CEO narsisizmi araştırmalarında kullanılan temel ölçüm araçları dört başlıkta değerlendirilmiştir: (1) CEO narsisizmi indeksi, (2) CEO'nun imza büyüklüğü, (3) CEO narsisizmi ölçekleri ve (4) üçüncü taraf değerlendirmeleri.

\subsection{CEO Narsisizmi İndeksi}

CEO narsisizminin ölçme yöntemlerinden birisi, araştırma bağlamında araştırmacının varlığının hedef kitle üzerinde etkisinin fark edilmediği "örtük ölçüm” (unobtrusive measures) yöntemidir. Bu ölçüm yönteminde organizasyonların CEO'larından doğrudan veri toplanmamakta, organizasyonların çeşitli arşiv verilerinden faydalanılmaktadır. Psikometrik öz-raporlama ölçümlerinden Narsisizm Kişilik Envanteri geçerli ve güvenilir bir ölçüm aracı olmasına rağmen (Samuel ve Widiger, 2008; Twenge ve Foster, 2008), organizasyonların üst düzey yöneticileri psikolojik test bataryalarına cevap vermekte oldukça isteksizlerdir (Cycyota ve Harrison, 2006; Patel ve Cooper, 2014). Narsisizm ölçümünün hassas doğası göz önüne alındığında, üst düzey yöneticiler öz-raporlama ölçümlerine katılım gösterse bile, sosyal istenirlik/beğenilirlik etkisi altında kalarak anket cevaplarını yanlı bir şekilde verebilir (Agnihotri ve Bhattacharya, 2019). Üst düzey yöneticilerden doğrudan anket cevapları toplamanın zorlukları dikkate alındığında, örtük ölçüm araçları oldukça geniş CEO popülasyonlarından geçerli, güvenilir ve objektif ölçümler elde etme imkânı sağlar (AlShammari vd. 2019). Bu bağlamda, narsistik kişiliğin ölçümlenmesinde örtük göstergelerin (unobtrusive indicators) kullanılması amacıyla, Chatterjee ve Hambrick $(2007,2011)$ CEO narsisizminin örtük göstergelerini geliştirmiş ve geçerlilik çalışmalarını yapmıştır.

Chatterjee ve Hambrick (2007) CEO narsisizminin gösterge seçimlerinde 2 temel kriter belirlemiştir. Illk kriter, her bir göstergenin üst düzey yöneticinin iradesini yansıtması gerekliliğidir. CEO'nun kişiliğini nitelendirebilmek için her bir göstergenin CEO'nun büyük oranda kontrolü altında olması ve temel olarak kurumsal ya da herhangi bir dış gücün tesiri altında kalmaması gerekir. íkinci kriter, her bir göstergenin narsistik kişiliğin bir ya da daha fazla unsurunu yansıtması gerekliliğidir. İkinci ölçütün şekillendirilmesinde Emmons (1987) tarafından belirlenen narsisizmin dört unsuru dikkate alınmıştır: Üstünlük/kibir, sömürme/haklıık, sadece kendisiyle ilgilenme/kendine hayranlık ve liderlik/otorite. Chatterjee ve Hambrick, bu iki ölçütle uyumlu olarak CEO narsisizminin beş göstergesini belirlemişlerdir: (1) organizasyonun yıllık raporlarında CEO'nun fotoğrafının ön planda olma düzeyi, (2) organizasyonun basın bültenlerinde CEO'nun ön planda olma düzeyi, (3) görüşmelerdeki ya da toplantılardaki CEO'nun birinci şahıs tekil zamirleri kullanımı, (4) CEO'nun nakit kazançlarının organizasyon içerisinde kendisinden sonra gelen en yüksek ücret alan yöneticinin kazançlarına bölünmesi, (5) CEO'nun nakit kazançlarının dışındaki imtiyazlarının kendisinden sonra gelen en yüksek yöneticinin imtiyazlarına bölünmesi. Bu göstergeler birleştirilerek 5 maddelik narsisizm indeksi oluşturulmuştur.

CEO narsisizm indeksinin birinci göstergesiyle ilgili olarak firmaların yıllık raporları, hem firmaların ilerleme ve büyüme beklentilerini raporlanması hem de firma liderlerinin kendilerini göstermesi için CEO'lara fırsat sağlar. CEO'lar yıllık raporların içeriğinin ve dizaynının şekillendirilmesinde oldukça dikkatlidirler. Yıllık raporlar içerisinde kendilerinin nasıl tasvir edildiğine yönelik güçlü yönlendirmeleri, fikirleri ve kontrolleri vardır. Narsisizmi yüksek düzeyde olan CEO'lar hem firma içerisindeki diğerlerinden daha önemli olduğunu gösteren güçlü bir deklarasyon olarak hem de vitrin çalışması olarak yıllık rapor içerisinde üst düzey görünürlük arayışı içerisinde olacaktır. CEO’ların fotoğraflarının önem düzeyiyle ilgili olan birinci göstergenin ölçüm değerlendirilmesi şu şekilde yapılmıştır: CEO'nun fotoğrafı bir sayfanın yarısından daha fazla alan kaplıyorsa ve sayfada sadece kendi fotoğrafı varsa 4 puan verilir; CEO'nun fotoğrafı bir sayfanın yarısından az yer kaplıyorsa ve CEO tek başına fotoğraf karesinde yer alıyorsa 3 puan verilir; CEO bir ya da daha fazla yöneticiyle fotoğraf karesinde yer alıyorsa 2 puan verilir; ve CEO'nun herhangi bir fotoğrafı yoksa 1 puan verilir.

Narsisizm indeksinin ikinci göstergesiyle ilgili olan şirket bültenlerinde kazançların sonuçları, yeni ürünler, büyük sözleşmeler, yeniden yapılandırmalar, büyük yeni iş alımları gibi çeşitli konularda bilgilendirmeler yer alır. Bu bilgilendirmelerin içeriği tamamen CEO'nun kontrolü altındadır (Chatterjee ve Hambrick, 2007). Narsisizm düzeyi yüksek olan CEO'ların vitrinde gözükme arzusu, kendilerinin önemini ve otoritesini dış paydaşlara hatırlatma ihtiyacı yüzünden, kendi adlarını bu bültenlerde daha sık göstermesi 
beklenmektedir (Zhu ve Chen, 2015). İkinci göstergenin ölçümü, basın bültenlerinde CEO'nun adı toplamda kaç kere geçiyorsa, basın bültenlerindeki toplam kelime sayısına bölünerek hesaplanmıştır.

Üçüncü göstergenin ölçüm sürecinde gazeteciler ya da finansal analistler tarafından CEO'larla yapılan görüşmelerin dijital transkriptleri kullanılmıştır. Sadece CEO'ların kelimelerini temsil eden görüşme kısımları izole edilerek, onların birinci tekil şahıs zamirlerini toplam kullanımı (ben, benim, benimki, kendim) çoğul zamirlerin toplam kullanım sayısına (biz, bizim, kendimiz) bölünerek üçüncü gösterge hesaplanmıştır (Chatterjee ve Hambrick, 2007).

Dördüncü göstergeyle ilgili olarak CEO’lar diğer yöneticilerin nakit kazançlarını kontrol ederler. Bu yüzden, narsistik CEO firma içerisinde kendisini diğerlerinden daha değerli, üstün ve yetenekli gördüğü için kendisinden sonra gelen en yüksek maaş alan yöneticiyle arasındaki kazanç farkı daha büyük olacaktır (Zhu ve Chen, 2015; Agnihotri ve Bhattacharya, 2019). Dördüncü göstergenin ölçümü CEO’nun nakit kazançları (maaş ve bonus) kendisinden sonra gelen en yüksek yöneticinin nakit kazançlarına bölünerek hesaplanmıştır. Beşinci göstergenin ölçümü ise CEO’nun nakit dışı kazanımlarının (gelecek yıl gelirleri, hisse senedi hibeleri, hisse senedi opsiyonları) kendisinden sonra gelen en yüksek yöneticinin kazanımlarına bölünerek hesaplanmıştır (Chatterjee ve Hambrick, 2007).

CEO narsisizm ölçümünün örtük ölçüm aracılı̆ıyla yapılmasının avantajlarından birisi katılımcının tepkiselliğini, istek karakteristiklerini ve araştırmacının beklentilerini elimine etmesidir. Katılımcıların kişiliklerini, algılamalarını, tercihlerini örtük ölçüm aracılığıyla öğrenmek araştırma sürecinde sosyal beğenirliğe uygun cevap verilmesini de bertaraf edebilir (Chatterjee ve Hambrick, 2007). Bu ölçüm aracının sağlamış olduğu avantajlardan birisi de bulgularının genelleştirebilir doğasının olmasıdır. Anket cevaplarını temel alınarak yapılan yorumlardan ziyade narsisizmi katılımcıların eylemlerinden yola çıkarak yorumlamak daha doğru sonuçlar verebilir (Al-Shammari vd., 2019). CEO narsisizm indeksinin kullanışlılığı ve faydalılığı önemli bir başarı ve içgörü sağlar. Bununla birlikte, bu yöntemin zayıflıkları vardır.

$\mathrm{Bu}$ indeksin en önemli zayıflıklarından birisi katılımcıların narsistik eğilimlerini kısmi ve dolaylı göstergelere dayanarak ölçüm yapmasıdır. Bu anlamda alan yazınındaki bazı çalışmalar, CEO narsisizm indeksinin göstergeleriyle narsisizmin çok boyutlu doğası arasında doğrudan bağlantı kuramamaktadır. Ayrıca, CEO narsisizm indeksindeki bazı göstergelerin CEO'nun kontrolü dışında olduğu belirtilmektedir. Örneğin, indeksin unsurlarından CEO'nun nakit ve nakit dışı kazançlarıyla ilgili göstergeleri bir firmanın büyüklüğü değişkeninden etkilenmektedir. Diğer bir deyişle, CEO'ların maaşları yüzde 40 oranında firmanın büyüklüğünden etkilenmektedir. Dahası, indeksin esas aldığı dokümanların hazırlanmasında CEO tam bir yetki içerisinde olmayabilir. Üst yönetim takımının, direktörlerin ve diğer paydaşların da kamuyla paylaşılan bilgilerin şekillendirmesinde etkisi olabilir (Wales vd., 2013; Cragun, Olsen ve Wright, 2019; Marquez-Illescas, Zebedee ve Zhou 2019). CEO narsisizm indeksinin kişilik zamiriyle ilgili göstergesini de eleştiren çalışmalar mevcuttur (Carey, Brucks, Küfner, Holtzman, Back, Donnellan ve Mehl, 2015). Bazı çalışmalar yeterli video ya da görüşme transkripti bulmada zorluk çektiğinden ve CEO'ların bu konuşmalarda kişilik zamiri kullanma konusunda daha dikkatli bir eğilim gösteren yapısından dolayı indeksin bu unsurunu çıkararak çalışmalarını tasarlamaktadır (Gerstner, König, Enders ve Hambrick, 2013). Bununla birlikte, kişilik zamirinin kullanımını diğer narsisizm ölçümleriyle birlikte kullanan çalışmalar vardır (O'Reilly III vd., 2018). Bu bağlamda CEO narsisizm indeksinin avantajları ve dezavantajları göz önüne alınmalıdır. Bu ölçüm aracı kullanılırken bahsedilen zayıflıklar dikkate alınarak diğer ölçüm araçlarıyla birlikte geçerliliği sağlanarak çalışmaların tasarlanması bilimsel titizlik ve sağlamlık kriterlerine daha uygun olacaktır.

\subsection{CEO'nun İmza Büyüklüğü}

Chatterjee ve Hambrick $(2007,2011)$ tarafından geliştirilen beş göstergeden oluşan CEO narsisizmi indeksine alternatif olarak Ham vd. (2017) ve Ham vd. (2018) tarafından CEO'ların imzalarını analiz etme aracılığıyla örtük ölçüm yöntemi geliştirilmiş ve bu yöntemin geçerlilik çalışmaları yapılmıştır. Bu çalışmaların temel mantığına göre imza boyutunun büyüklüğü CEO'ların görkemli doğasını temsil eder (Cragun vd., 2019). İmza büyüklüğü ve narsisizm arasındaki ilişki psikoloji literatüründe uzun zamandır çalışılmaktadır. Psikoloji alanında gerçekleştirilen çalışmalara göre, imzaları görece daha büyük olan bireylerin şişirilmiş bir öz-benlik inancına sahip oldukları ve sürekli bir haklı olma duygusu içerisinde oldukları bulunmuştur. İmzası görece daha büyük olan bireylerin kendilerini daha üstün hissetme, diğerlerini kontrol etme ve baskı altında tutma 
eğiliminde oldukları bulunmuştur. Psikoloji alanında kullanılan imza büyüklüğü aracılı̆ııla, narsisizmi ölçme yönteminin geçerlilik çalışmalarının yapılması amaçlanmıştır. Bu amaçla laboratuvarda lisans öğrencileriyle gerçekleştirilen çalışmalar yapılmıştır. Öğrencilerin imza büyüklükleri ve Narsistik Kişilik Envanteri skorları arasındaki ilişkiye bakılarak, öğrencilerin narsisizm düzeyini belirlemede imza büyüklüklerinin geçerli ve güvenilir ölçüm aracı olduğunu bulmuşlardır (Ham vd., 2017). İmza büyüklüğünü ölçüm aracı olarak kullanan çalışmalarda, her bir katılımcının imzalarını çevreleyen bir dörtgen çizilerek ölçüm süreci başlatılır. Dörtgenin her bir kenarı imzaların en uç noktasına değecek şekilde çizilir. İmzaların etrafını saran dörtgen alanın genişliği ve uzunluğu birbiriyle çarpılarak imza alanı hesaplanır. Katılımcıların adlarının imza büyüklüğünü etkileyeceği dikkate alındığında hesaplanan alan katılımcıların adlarındaki harf sayısına bölünür (Ham vd., 2019; Chen, Zhang ve Jia, 2019).

İmza büyüklüğü bireysel egoyu ölçmede kullanılır. Çünkü katılımcıların kişiliklerine yönelik doğrudan soru sormayı gerektirmez ve katılımcılar egolarının imzalarını etkilediklerini fark etmemiş olabilirler. İnsanların gizli egoları olduğu dikkate alındığında imza aracılığıyla narsisizm ölçümünün yapılması narsisizm ölçümünde sosyal beğenirliğe göre cevap verme etkisini minimize edebilir (Rudman, Dohn ve Fairchild, 2007). Narsisizm ölçümündeki kısıtlardan birisi gerekli datayı toplamanın zorluğu ve zaman alıcı doğasıdır. Bununla birlikte, çoğu firma paydaşlarına yıllık raporlarını gönderir ya da web sitelerinde bu tarz raporların dijital kopyaları yer alır. Bu raporlarda CEO'ların imzaları gözlemlenebilir. Bu açıdan imza büyüklüğü CEO narsisizmini ölçmede kolaylık sağlayabilir (Ham vd., 2018). Bununla birlikte, imza büyüklüğü CEO'ların eğitiminden, alışkanlıklarından ve kaligrafi eğitiminden etkilenebilir (Chen vd., 2019). İmza büyüklüğü CEO'ların direkt kontrolünde olan bir davranışı yakalamış olma avantajına rağmen, narsisizmin çok boyutlu doğasını tamamen yakalamada işlevsel olmayabilir (Cragun vd., 2019).

\subsection{CEO Narsisizmi Ölçekleri}

CEO narsisizminin ölçülmesi için üst düzey yöneticilerden narsisizm ölçekleri aracılığıyla veri toplamak zor ve zaman alıcı olmasına rağmen, mevcut çalışmalar CEO narsisizmini doğrudan ölçümleyebilecek psikolojik öz-raporlama araçlarıyla veri toplanması yönünde çağrılar yapmaktadır. Bu bağlamda, CEO narsisizmiyle ilgili araştırmalarda kullanılan tek ölçüm aracı Narsisizm Kişilik Envanteridir (Tang, Mack ve Chen, 2018; Cragun vd., 2019). Bu kişilik envanterinin 40 soruluk orijinal versiyonu narsisizmin geçerli ve güvenilir bir ölçümünü temsil ederken (Raskin ve Terry, 1988), Ames, Rose ve Anderson (2006) bu envanterin 16 soruluk daha kısa versiyonunun gelişimine katkı sağlamıştır.

CEO narsisizmi araştırmalarında kullanılan Narsisizm Kişilik Envanteri narsisizm ölçümünü tek boyutlu bir yapı olarak ele alır (She, Li, London, Yang ve Yang, 2019). Bununla birlikte, sosyal psikoloji ve kişilik araştırmaları alan yazınında narsisizmin iki boyutlu yapısını temsil eden hayranlık (admiration) ve rekabet (rivalry) boyutlarına yönelik geliştirilmiş ölçek çalışması bulunmaktadır. Narsisizmin hayranlık boyutunun motivasyonel arka planında, kişi kendi görüşlerini aşırı beğenir ve görüşlerinin pozitif ve makul olduğunu destekleyen sürekli öz-geliştirme faaliyetleri içerisinde bulunur. Rekabet boyutunda ise kişi kendisini etrafındaki olası tehditlere karşı koruma refleksi gösterir. Kişi kendisi hakkındaki negatif görüşlere karşı savunma psikolojisi içerisinde hareket eder. Narsisizmin hayranlık boyutunda kişinin sloganik odağı "ben müthiş bir insanım, bu yüzden etrafımdakilerin bana hayran olmasına izin vermeliyim" iken, rekabet boyutunda kişinin sloganik odağı "diğerlerinin beni küçük düşürmesine izin vermemeliyim" ifadesidir. Narsisizmin hayranlık boyunda narsist kişi kendinden emin, baskın ve açıklayıcı davranışlarıyla sosyal statü, başarı, takdir, sosyal ilgi ve lider seçilme gibi istenen sosyal sonuçlara kavuşur. Narsisizmin rekabet boyutunda narsist kişi diğerlerini küçük görür, onların hislerine karşı hassas davranmaz ve diğerlerinden üstün olduğunu kendisine sürekli kanıtlamaya çalışır. Öfkeli, düşmanca ve sosyal olarak duygusuz davranan bu narsist tipler reddedilme, eleştiri ve güvensizlik gibi negatif sonuçlarla karşılaşırlar. Her iki narsisizm tipinde ortak olan bu kişilerin görkemli bir benlik algısına sahip olmalarıyken; duygu, düşünce ve davranış açısından farklılıkları bulunmaktadır (Back vd., 2013).

Back vd. (2013)'nin geliştirmiş olduğu narsisizminin iki boyutlu ölçek çalışması narsisizmin alan yazınındaki birbiriyle çelişen sonuçlarını daha iyi açıklayabilir. Narsisizmin tek boyutlu ölçümünden ziyade iki boyutlu ölçümü tercih edilirse boyutların çıktılar üzerindeki farklı etkisi gözlemlenebilir. Örneğin, duygu yönetimi konusunda yapılan bir çalışmaya göre, narsisizmin hayranlık boyutu, duygulara problemli bir şekilde 
tepki verme ve duyguların zayıf bir şekilde okunmasıyla ilgili negatif bir şekilde ilişkili bulunmuşken; narsisizmin rekabet boyutu her iki tip duygusal düzensizlikle pozitif bir şekilde ilişkili bulunmuştur. Diğer bir deyişle, narsisizmin hayranlık boyutundaki kişilerin, duygusal deneyimlerini narsisizmin rekabet boyutundaki kişilere göre daha etkili bir şekilde yönetebildiği bulunmuştur (Cheshure, Zeigler-Hill, Sauls, Vrabel ve Lehtman, 2020).

Narsisizmin iki boyutunun konuşma performansıyla ilişkisini belirlemeye yönelik yapılan çalışmada ise, narsisizmin hayranlık boyutunda skorları yüksek olan kişilerin konuşma performansının daha yüksek değerlendirme puanı aldığı ve bu kişilerin konuşma esnasında daha düşük düzeyde endişeli olduğu bulunmuştur (Manley, Paisarnsrisomsuk ve Roberts, 2020). Narsisizmin bu iki boyutunun kişilik özellikleriyle olan ilişkisinde farklılık gösterip göstermediğine yönelik yapılan çalışmada ise, hayranlık boyutunun dışa dönüklük ve vicdanlılık kişilik özellikleriyle pozitif bir şekilde ilişkili olduğu, rekabet boyutunun ise uyuşmazlık özelliği ile pozitif bir şekilde ilişkili olduğu ve rekabet boyutunun duygusal istikrarlılık ve vicdanlılık özellikleriyle negatif bir şekilde ilişkili olduğu bulunmuştur. Değerler açısından ilişkisine bakıldığında, hayranlık boyutu değişime açıklık ve başarı değerleriyle ilişkiliyken, rekabet boyutu ise güç baskınlığı ve güç kaynakları ile ilişkili bulunmuştur (Rogoza, Wyszyńska, Maćkiewicz ve Cieciuch, 2016). Bu sonuçlardan yola çıkarak, Back vd. (2013)'nin geliştirdiği iki boyutlu narsisizm ölçeğinin kompleks ilişkileri açıklamada daha işlevsel olduğu söylenebilir.

\section{4. Üçüncü Taraf Değerlendirmeleri}

Geçerliliği ve güvenilirliği kabul görmüş psikometrik ölçeğin avantajlarından faydalanmak ve CEO'lara ulaşmanın zorluğunun üstesinden gelmek amacıyla bazı çalışmalar CEO narsisizminin ölçümlenmesinde üçüncü taraf uzmanlardan istifade etmeyi tercih etmiştir (Cragun vd., 2019). Örneğin, CEO'ların kamuoyundaki çeşitli video konuşmalarından oluşan video örneklemi, kişilik ölçümü konusunda uzmanlaşan doktora öğrencilerine izletilerek Narsistik Kişilik Envanteri aracılığıyla CEO'ların narsisizm düzeyinin değerlendirilmesi sağlanmıştır (Petrenko vd., 2016). Üçüncü taraf uzmanları mevcut çalışmaların CEO narsisizmi ölçümünün geçerlilik çalışmalarında da kullanılmaktadır. Örneğin, CEO narsisizm indeksi ölçümünün geçerliliğini sağlamak amacıyla CEO'larla yüz yüze gerçekleştirilmiş 76 videoya ulaşılmış, bu videolar iki deneyimli psikoloğa izletilmiş ve psikologların bağımsız bir şekilde Narsistik Kişilik Envanterini doldurması sağlanmıştır. Çalışma sonuçlarına göre iki deneyimli psikoloğun bağımsız değerlendirmeleri arasında yüksek düzeyde uyum bulunduğu gibi, CEO narsisizm indeksinin geçerliliğini sağlamaya yönelik de güçlü bulgulara ulaşılmıştır (Zhu ve Chen, 2015). Üçüncü taraf uzmanların kullanıldığı bir diğer örnek ise, Resick, Whitman, Weingarden ve Hiller (2009) tarafından gerçekleştirilen çalışmadır. Bu çalışmada üçüncü taraf uzmanlara narsisizmin tanımı aktarılmış ve narsisizmin temel özellikleriyle ilgili sekiz sıfat (örneğin kibirli, iddialı, övünen, benmerkezci, gösterişli) verilmiştir. Üçüncü taraf uzmanlardan CEO’ların biyografilerinden yola çıkarak bu sekiz sıfat aracılığıyla CEO’ların narsistik eğilimlerinin puanlanması istenmiştir.

Üçüncü taraf uzman değerlendirmeleri, öz-rapor değerlendirmelerine göre daha yüksek düzeyde kişilik ölçümü geçerliliği sağlar ve öz-raporlama ölçümlerindeki sosyal beğenirlik sorununa yakalanmaz. Çünkü uzman gözlemciler hedef kitlenin kişilik özelliklerini belirlemede daha objektif bakış açılarına sahiptir. Üçüncü parti uzmanları örtük ölçüm yöntemi içerisinde yer alır ama hedef kitleye yönelik doğrudan ve geçerli bir yöntemi temsil eder (Petrenko vd., 2016). Bununla birlikte, üçüncü parti uzmanları bulmak zor olabilir. Üçüncü parti uzmanların bir örgüt içerisinde CEO'yu değerlendirme seçeneği tercih edildiğinde CEO'yu değerlendirmek vakit alıcı olabilir. CEO'yu değerlendirmek için onunla yakın temas da gerektirebileceği için ulaşılabilirlik açısından sıkıntı oluşturabilir. CEO'ları onların videoları aracığıyla değerlendirme seçeneğinde ise her CEO'nun video konuşmalarının olmayabileceği göz ardı edilmemelidir (Cragun vd., 2019). Bu bağlamda üçüncü parti uzmanlar aracılığıyla CEO narsisizmi değerlendirme sürecinde bu yöntemin avantajlarının ve dezavantajlarının sağlıklı bir şekilde değerlendirilmesi gereklidir.

\section{Araştırmanın Metodolojisi}

CEO narsisizmiyle ilgili literatür tarama sürecinde, Rudolph, Murphy ve Zacher (2020)'ın "sağılıkı liderlikle" ilgili literatürü tarama sürecinde izlemiş oldukları adımlar takip edilmiştir. Şekil 1'de CEO narsisizmine yönelik gerçekleştirilen literatür tarama sürecini gösteren akış şeması yer almaktadır. 
Şekil 1. Literatür Tarama Sürecinin Akış Şeması

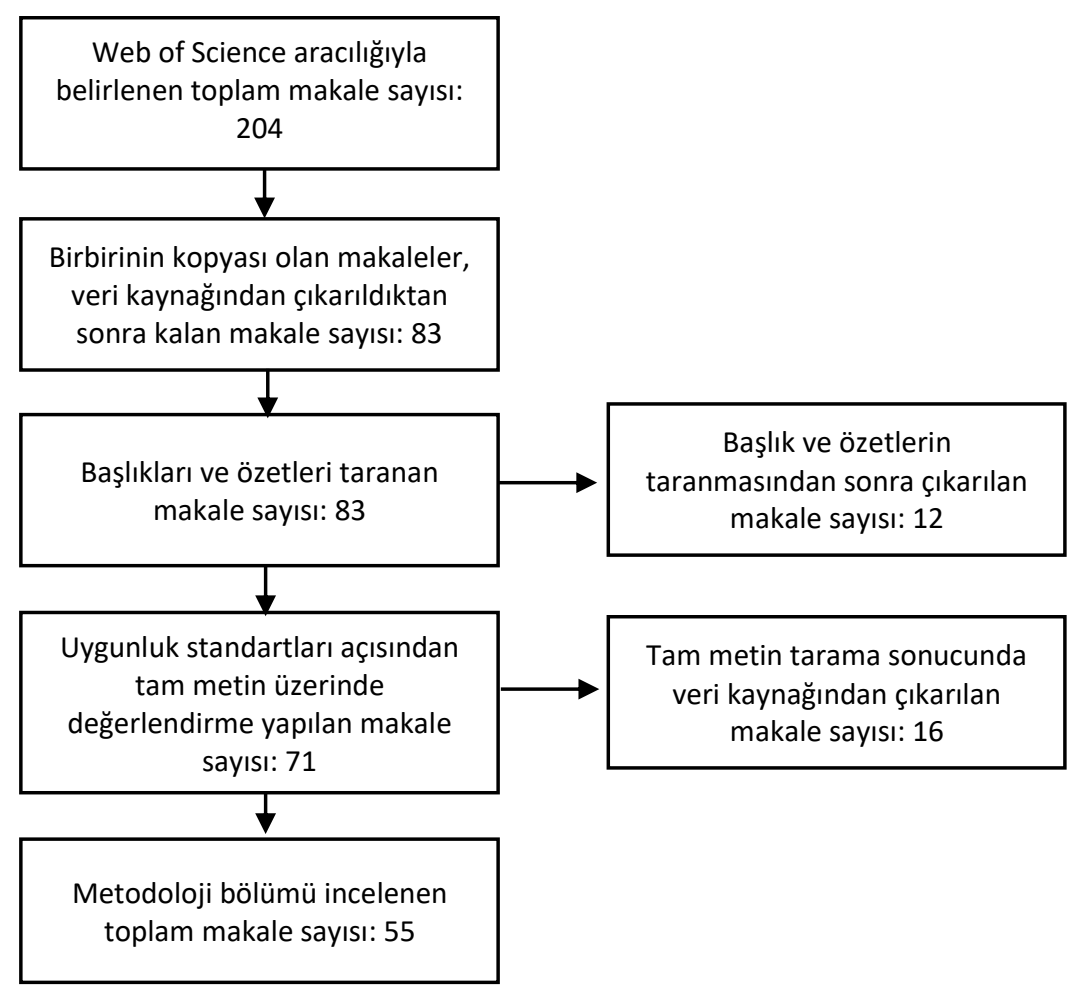

Web of Science (WOS) veri tabanını kullanarak, CEO narsisizmi konusuna odaklanan makaleler belirlenmeye çalışılmıştır. CEO narsisizmiyle ilişki olan çeşitli anahtar kelimeler (örneğin, "CEO narcissism", "narcissistic CEO", "narcissistic CEOs") WOS kapsamındaki makalelerin başlıklarında, anahtar kelimelerinde ve özetlerinde taranmıştır. Bu süreç sonunda toplamda 204 makaleye ulaşıımıştır. 204 makale içerisinde aynı makalenin bir veya birden fazla kopyası olan 121 makale (duplicate references) çalışmanın örnekleminden çıkartıldıktan sonra örneklemimizde 83 makale kalmıştır. Bu makalelerin CEO narsisizm araştırmalarıyla ilgili olup olmadığının tespit edilmesi amacıyla başlık ve özet kısımları taranmıştır. Bu tarama sonucunda, başlığında veya özetinde narsisizm terimi geçmeyen, üst düzey yöneticilerin narsistik eğilimlerine odaklanmayan 12 makale veri kaynağından çıkarılmıştır. Böylece, veri kaynağında 71 makale kalmıştır.

Son aşamada, veri kaynağına dahil etme kriterleri kapsamında 71 makalenin tam metninde derinlemesine tarama yapılmıştır. Çalışmanın amacı CEO narsisizminin ölçüm sürecini aydınlatmaktır. Bu anlamda, CEO narsisizmiyle ilgili nicel ya da nitel araştırma tasarımı olan makaleler, veri kaynağına dahil etme kriteri olarak belirlenmiştir. Diğer bir deyişle, çalışmanın veri kaynağı CEO narsisizmiyle ilgili yapılmış ampirik çalışmalarla sınırlandırıımıştır. İkinci dahil etme kriteri, CEO'ların ya da üst düzey yöneticilerin narsisizmiyle ilgili ampirik çalışmaları veri kaynağına dahil etmektir. Çalışan narsisizmi, herhangi bir yönetici ya da lider narsisizmi çalışma kapsamında değildir çünkü çalışmanın amacı CEO narsisizminin ölçüm süreciyle ilgilidir. Üçüncü bir kriter olarak, WOS kapsamındaki dergilerde sadece ingilizce dilinde yayınlanmış makaleler veri kaynağına dahil edilmiştir. Makalelerin tam metninde bu uygunluk standartlarının karşılanmadığı 16 çalışma veri kaynağı dışında bırakılmıştır. Sonuç olarak, CEO narsisizm araştırmalarının metodoloji bölümünü incelenebileceği 55 çalışma kalmıştır. Bu 55 çalışma nihai veri kaynağını olarak belirlenmiştir.

CEO narsisizmiyle ilgili 55 ampirik makale, aşağıda yöneltilen sorular açısından incelenmiştir: (1) CEO narsisizmi araştırmaları hangi ülkelerde faaliyet gösteren firmaların CEO'larını sıklıkla odağa almıştır? (2) CEO narsisizmi araştırmaları hangi sektörlerde faaliyet gösteren firmaları örneklem olarak belirlemiştir? (3) CEO narsisizmi araştırmaları hangi disiplinlerle ilişkili dergilerde daha sık yayınlanmaktadır? (4) CEO narsisizm araştırmalarında arşiv verisi kullanan makaleler hangi veri kaynaklarından faydalanmaktadır? (5) CEO narsisizm araştırmalarında sıklıkla kullanılan ölçüm araçları nedir ve ölçüm süreci açısından araştırmacıların benimsediği ortak bir ölçüm süreci var mıdır? (6) CEO narsisizm araştırmalarında CEO narsisizminin 
ölçümünün sağlamlaştırılması amacıyla gerçekleştirilen ilave (kavramsal) geçerlilik analizleri kapsamında hangi CEO narsisizmi ölçüm araçları kullanılmıştır?

\section{Araştırma Bulguları}

CEO narsisizm araştırmalarının hangi ülkelerde faaliyet gösteren firmalara odaklandığıyla ilgili olarak, 26 çalışmanın ABD, 7 çalışmanın Çin, 2 çalışmanın Hindistan, 2 çalışmanın Pakistan, 2 çalışmanın Güney Kore, 2 çalışmanın İngiltere, 1 çalışmanın Almanya, 1 çalışmanın Tayvan, 1 çalışmanın Malezya ve 1 çalışmanın İran firmalarına odaklandığı bulunmuştur. 8 çalışma Fortune 500 ya da 1000 firmaları içerisinde olan firmaları tercih ettiği için bu çalışmaların ülke açısından çeşitlilik gösterdiği bulunmuştur. 2 çalışmada ise herhangi bir ülke belirtilmemiştir.

CEO narsisizm araştırmalarının sektörel açıdan, aynı sektörde yer alan firmaların CEO'larını örneklem olarak seçtiği gibi, birbirinden farklı sektörlerde faaliyet gösteren firmaların CEO'larını da örneklem olarak seçtiği bulunmuştur. Tek bir sektör üzerinden örneklem alan çalışmalar, bilgisayar donanımı ve yazılım endüstrileri, imalat firmaları, ilaç firmaları, bankalar, elektronik endüstrisi, otomotiv endüstrisi sektörlerini odağa almıştır. Çeşitli sektörleri aynı çalışmada örneklem olarak ele alan CEO narsisizmi çalışmaları ise, Fortune 500/1000 firmalarını ya da S\&P 500/1000'de yer alan yüksek teknoloji faaliyeti gösteren firmaları odağa almıştır.

CEO narsisizm araştırmalarından 43 çalışmanın işletme alanıyla ilgili dergilerde yayınlandığı, 12 çalışmanın ekonomi, maliye ve finans alanıyla ilişkili dergilerde yayınlandığı bulunmuştur. İşletme alanında en sık yayınladığı dergiler Administrative Science Quarterly, Leadership Quarterly, Strategic Management Journal, Journal of Management, Journal of Business Ethics, International Business Review adlı dergilerdir. Ayrica, Journal of Management Studies, Journal of the Academy of Marketing Science, Journal of Business Research, Journal of Business Venturing adlı dergilerde de CEO narsisizm çalışmaları yayınlanmaktadır. Ekonomi ve finans alanında ise, Review of Behavioral Finance, Review of Accounting Studies, The Journal of the American Taxation Association, Accounting Horizons, Abacus adlı dergilerde CEO narsisizmi çalışmaları yayınlanmaktadır.

CEO narsisizm araştırmalarında arşiv verisi kullanan araştırmaların hangi veri kaynaklarından yararlandığı tespit edilmeye çalışıımıştır. Bu anlamda, CEO narsisizmini indeksi aracılı̆ı̆yla narsistik eğilimleri ölçmeye çalışan CEO narsisizmi araştırmalarının (1) CEO'nun fotoğraflarıyla ilgili gösterge için "Mergent Online" ve firmaların internet siteleri, (2) CEO'nun isminin sıklığıyla ilgili gösterge için Factiva'daki firma bültenleri, (3) CEO'nun birinci tekil şahıs kullanımı göstergesi için "Lexis-Nexis akademik datası" ve "Wall Street transkripti", (4) CEO'nun nakit kazanç oranı ve (5) nakit dışı kazanç oranı göstergeleri için "Execucomp" veri kaynaklarından yararlandığı bulunmuştur.

Biyografi verisi kullanarak CEO narsisizmi araştırmalarını tasarlayan çalışmalar ise, "Who's Who European Business Manager" ve "Marquis Who's Who" biyografi veri kaynaklarından yararlanmıştır. İmza verisi kullanan çalışmalar ise çoğunlukla el yordamı ile çeşitli kaynaklardan veri toplamaktadır. SEC (Securities and Exchange Commission) ve CNINFO (Chinese Securities Regulatory Commission) internet sitelerinden imza verisi toplayan çalışmalar olduğu bulunmuştur. CEO'ların narsistik eğilimlerini videolar aracılığıyla değerlendiren çalışmalar ise, kamuya açık internet kaynaklarından veri toplamaktadır.

Tablo 1'de CEO narsisizmiyle ilgili ampirik çalışmaların CEO'ların narsistik eğilimlerini nasıl ölçümlediği gösterilmiştir. Ölçüm araçlarının ilk türü olarak, Chatterjee ve Hambrick'in 2007 yılında geliştirmiş oldukları CEO narsisizm indeksinin 5 göstergesi Tablo 1'e yerleştirilmiştir: (1) CEO'nun fotoğrafının büyüklüğü, (2) CEO'nun isminin sıklığı, (3) CEO'nun birinci tekil şahıs kullanımı, (4) CEO'nun nakit kazancı oranı, (5) CEO'nun nakit dışı kazanç oranı. CEO narsisizm indeksinin sonrasında sırayla, CEO’nun imza büyüklüğü, ölçek, üçüncü taraf değerlendirmeleri, biyografi ve sosyal medya ölçüm araçları tabloya konumlandırılmıştır. 


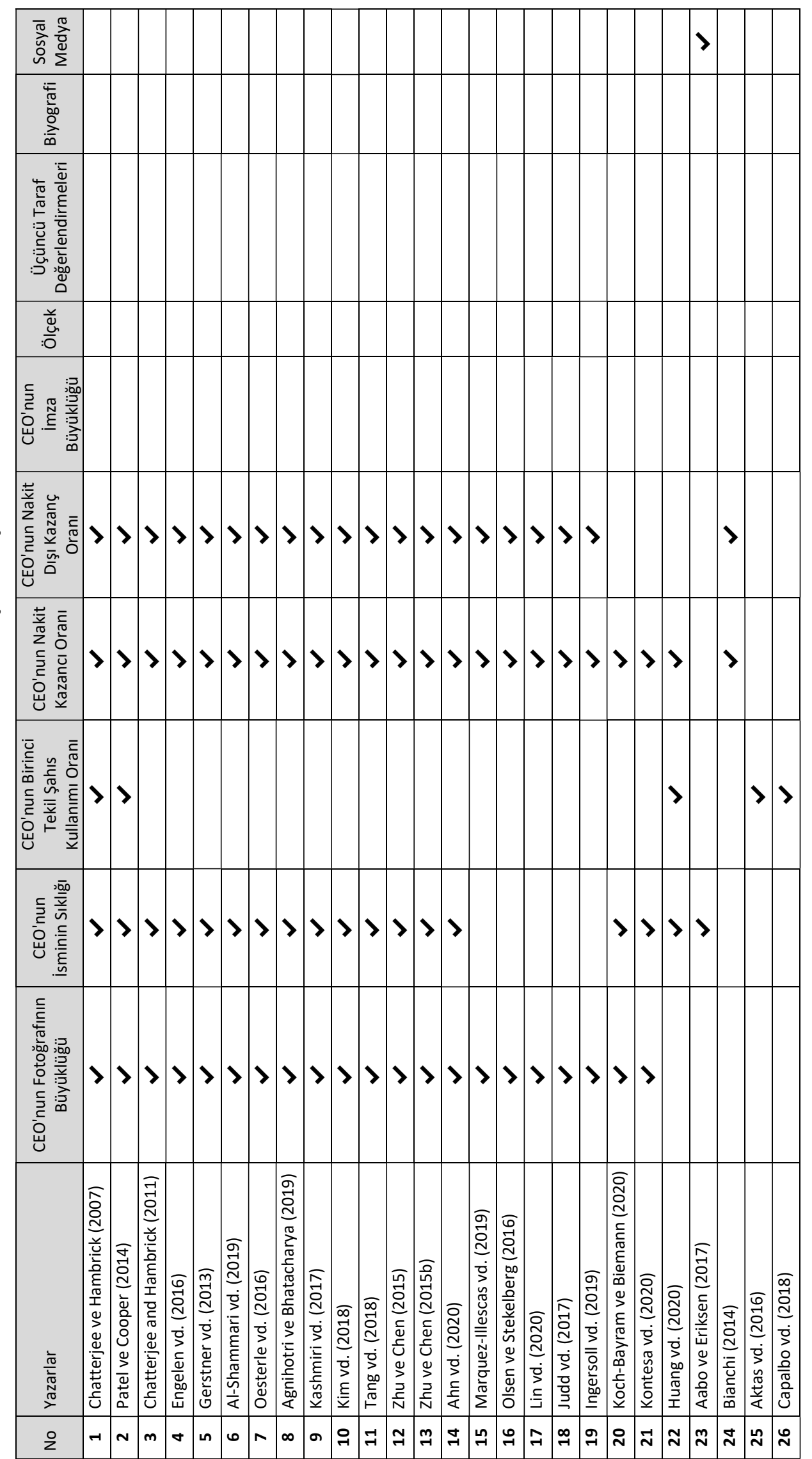




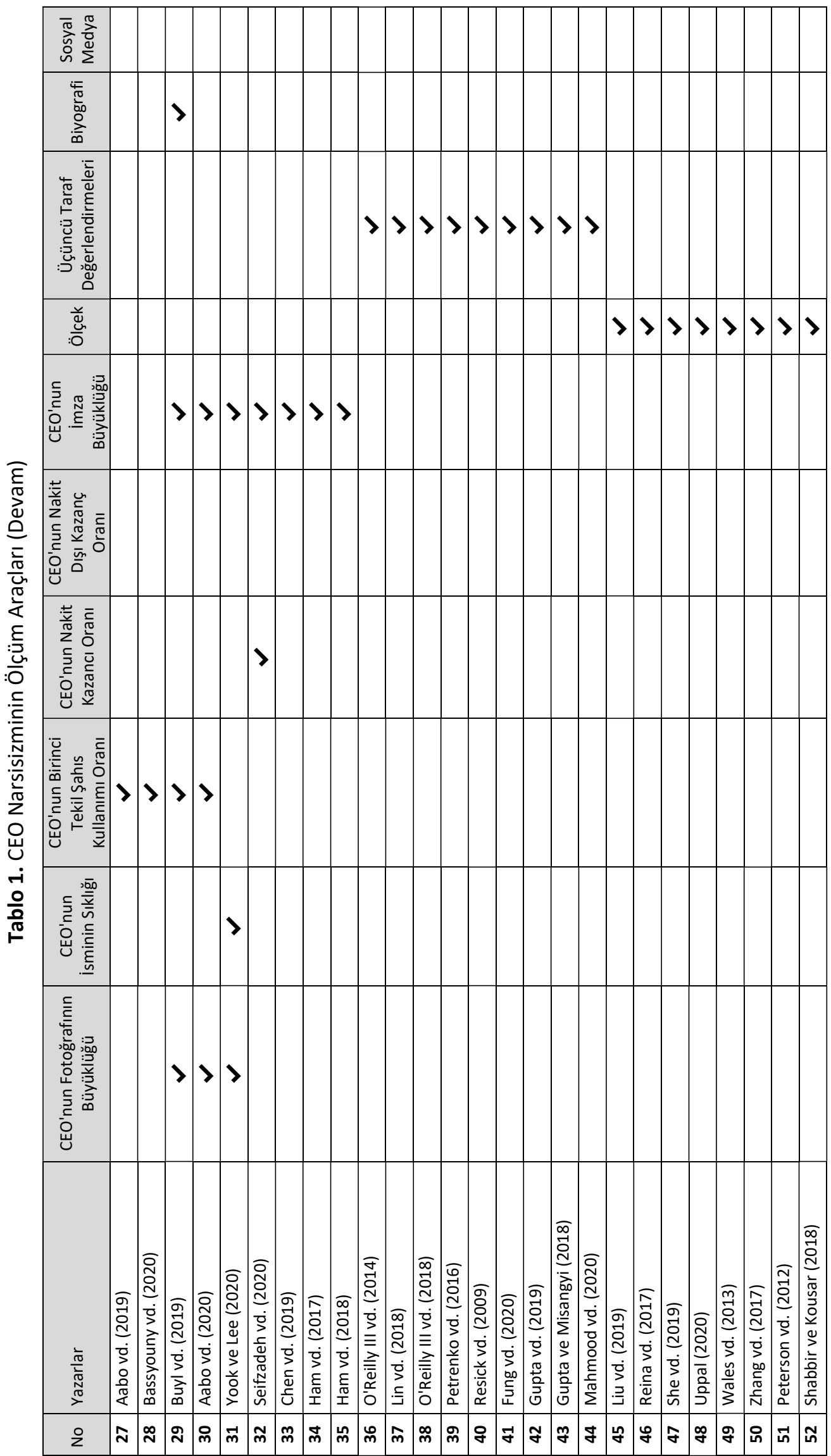


Tablo 1'de görüldüğü üzere alan yazınında en sık kullanılan ölçüm aracı 5 göstergeden oluşan Chatterjee ve Hambrick'in 2007 yılında geliştirmiş oldukları CEO narsisizm indeksidir. CEO narsisizm indeksi ilk geliştirildiğinde 5 gösterge olarak kullanılmaktaydı. Bununla birlikte, alan yazınındaki çalışmaların indeksin 5 göstergeden oluşan formunun bazı göstergelerini çıkartarak çalışmalarında kullandıkları görülmektedir. Bu anlamda, CEO'ların narsistik eğilimlerinin ölçümlenmesinde temel olarak narsisizm indeksini kullanan toplam 32 çalışmadan; 2 çalışma narsisizm indeksinin bütün göstergelerini, 12 çalışma narsisizm indeksinin 4 göstergesini, 8 çalışma narsisizm indeksinin 3 göstergesini, 4 çalışma narsisizm indeksinin 2 göstergesini, 6 çalışma narsisizm indeksinin 1 göstergesini kullanmaktadır. Bu bağlamda, narsisizm indeksinin standart bir kullanımının olmadığı görülmektedir. CEO narsisizm indeksinin 1 ve 2 göstergeden oluşan formunu kullanan çalışmaların CEO narsisizm ölçümünün daha kuvvetli bir şekilde ölçümlenebilmesi için alternatif ölçüm araçlarını bir arada kullandığı görülmektedir (örneğin CEO’nun imza büyüklüğü, biyografi, sosyal medya analizi).

CEO'ların narsistik eğilimlerinin ölçümlenmesinde 7 çalışmanın CEO'nun imza büyüklüğü aracılığıyla ölçüm sürecini gerçekleştirdiği görülmektedir. Bu 7 çalışmadan 4 çalışma narsistik eğilimlerin daha sağlam bir şekilde ölçümlenebilmesi için farklı ölçüm araçlarından faydalandığı görülmektedir (örneğin CEO narsisizm indeksi ve biyografi).

CEO narsisizminin ölçümlenmesinde 9 çalışmanın üçüncü taraf değerlendirmeleri aracılığıyla ölçüm sürecini gerçekleştirildiği görülmektedir. Bu çalışmalarda üçüncü taraf kişiler (kişilik değerlendirmesi deneyimi olan psikoloji alanında doktora öğrencileri, işletme alanından mezun olmuş öğrenciler, firma çalışanları), çeşitli ölçüm araçlarıyla (Resick ve diğerlerinin geliştirmiş olduğu Narsistik Kişilik Envanteri, Ames ve diğerlerinin geliştirmiş olduğu Narsistik Kişilik Envanterinin 16 maddelik formu) veri kaynakları üzerinden (örneğin, CEO’ların videolarını içeren halka açık internet kaynakları) CEO'ların narsistik eğilimlerini değerlendirmiştir.

CEO narsisizminin ölçüm sürecinde 8 çalışmanın CEO'lara doldurtulan ölçek aracıllı̆ıyla öllçüm sürecini gerçekleştirdiği görülmektedir. Bu çalışmalarda Ames vd. (2006)'nin 16 maddelik Narsistik Kişilik Envanteri kullanılarak CEO'ların narsistik eğilimleri belirlenmiştir. Bu ölçüm sürecinde doğrudan CEO'ların Narsistik Kişilik Envanterini doldurması sağlanmıştır.

CEO narsisizminin ölçüm sürecini sağlamlaştırmak için 20 adet CEO narsisizmi araştırmasının standart geçerlilik analizleri yaptıktan sonra, ilaveten ya da destekleyici mahiyette kavramsal geçerlilik analizleri yaptığı bulunmuştur. 20 çalışmanın ilave ya da destekleyici geçerlilik analizlerini hangi ölçüm aracıyla yaptığı Tablo 2'de gösterilmiştir.

Tablo 2'de yer alan $\star$ işareti, ilgili çalışmanın temel olarak kullandığı ölçüm aracına yönelik ilave ya da destekleyici kavramsal geçerlilik çalışmasını, hangi ölçüm aracını kullanarak gerçekleştirdiğini ifade etmektedir. Diğer bir deyişle, yıldız işareti, ilgili çalışmaların kavramsal geçerlilik çalışmasını hangi CEO narsisizmi ölçüm aracıyla yerine getirdiğini ifade etmektedir. Illave geçerlik analizi yapan 20 çalışmanın 13'ü üçüncü taraf değerlendirmeleri aracılığıyla kavramsal geçerlilik analizlerini yaptığı görülmektedir. 13 çalışma içerisinden 3 çalışmanın hem CEO narsisizmi indeksi göstergelerini hem üçüncü taraf değerlendirmelerini geçerlilik çalışmalarında kullandığı görülmektedir. Geçerlilik analizi kapsamında kullanılan üçüncü taraf değerlendirmelerinde, üçüncü taraf kişiler (örneğin, güvenlik analistleri, hisse senedi analistleri, klinik psikoloji araştırmacıları, firma çalışanları) 40 maddelik Narsistik Kişilik Envanteri (Raskin ve Terry, 1988), 16 maddelik Narsistik Kişilik Envanteri (Ames vd., 2006), Aşırı Duyarlılık Narsisizm Ölçeği (Hendin ve Cheek, 1997), Dürüstlük-Tevazu Ölçeği (Ashton, Lee ve De Vries, 2014), Büyük Beşli Kişilik Değerlendirmeleri (Gosling, Rentfrow ve Swann Jr, 2003) aracılığıyla CEO'ların narsistik eğilimlerini değerlendirmişlerdir. Böylece, CEO narsisizminin ölçüm sürecinde Tablo 1'de kullandıkları ölçüm araçlarına ilaveten, Tablo 2' deki ölçüm araçlarını ilave geçerlilik çalışması için kullanarak CEO narsisizm ölçümünü sağlamlaştırmışlardır.

Tablo 2'deki 20 çalışmadan 7 çalışmanın CEO narsisizmi indeksinin göstergeleri aracılığıyla kavramsal geçerlilik çalışmalarını yaptığı görülmektedir. Orijinalinde 5 göstergeden oluşan narsisizm indeksinin göstergelerinin azaltılmış versiyonlarının geçerlilik çalışmalarında kullanıldığı görülmektedir. 20 çalışmadan 2 çalışma ölçek aracılığıyla geçerlilik analizlerini yapmışken, 1 çalışma içerik analiziyle geçerlilik çalışmalarını 
yapmıştır. İçerik analizini kavramsal geçerlilik çalışması kapsamında kullanan ilgili çalışmada, bankaların hissedarlara gönderdiği CEO tarafından imzalanmış mektuplar, Short vd. tarafından 2010 yılında geliştirilen bilgisayar destekli içerik analizine tabi tutularak CEO narsisizminin kavramsal geçerlilik çalışması gerçekleştirilmiştir.

Tablo 2. İlave ya da Destekleyici Geçerlilik Analizleri Kapsamında Kullanılan CEO Narsisizminin Ölçüm Araçları

\begin{tabular}{|c|c|c|c|c|c|c|c|c|c|c|}
\hline No & Yazarlar & $\begin{array}{l}\text { CEO'nun } \\
\text { Fotoğrafının } \\
\text { Büyüklüğü }\end{array}$ & $\begin{array}{l}\text { CEO'nun } \\
\text { İsminin } \\
\text { Sıklığı }\end{array}$ & $\begin{array}{c}\text { CEO'nun } \\
\text { Birinci Tekil } \\
\text { Şahıs } \\
\text { Kullanımı } \\
\text { Oranı }\end{array}$ & $\begin{array}{c}\text { CEO'nun } \\
\text { Nakit } \\
\text { Kazancı } \\
\text { Oranı }\end{array}$ & $\begin{array}{c}\text { CEO'nun } \\
\text { Nakit } \\
\text { Dışı } \\
\text { Kazanç } \\
\text { Oranı }\end{array}$ & $\begin{array}{l}\text { CEO'nun } \\
\text { İmza } \\
\text { Büyüklüğü }\end{array}$ & Ölçek & $\begin{array}{l}\text { Üçüncü } \\
\text { Taraf } \\
\text { Değerlen- } \\
\text { dirmeleri }\end{array}$ & $\begin{array}{c}\text { İçerik } \\
\text { Analizi }\end{array}$ \\
\hline 1 & $\begin{array}{l}\text { Chatterjee ve } \\
\text { Hambrick (2007) }\end{array}$ & & & & & & & & $\star$ & \\
\hline 2 & $\begin{array}{l}\text { Patel ve Cooper } \\
(2014)\end{array}$ & & & & & & & & $\star$ & \\
\hline 3 & $\begin{array}{l}\text { Gerstner vd. } \\
\text { (2013) }\end{array}$ & & & & & & & & $\star$ & \\
\hline 4 & $\begin{array}{l}\text { Zhu ve Chen } \\
\text { (2015) }\end{array}$ & & & & & & & & $\star$ & \\
\hline 5 & $\begin{array}{l}\text { Zhu ve Chen } \\
\text { (2015b) }\end{array}$ & & & & & & & & $\star$ & \\
\hline 6 & Gupta vd. (2019) & & & & & & & & $\star$ & \\
\hline 7 & $\begin{array}{l}\text { Gupta ve Misangyi } \\
\text { (2018) }\end{array}$ & & & & & & & & $\star$ & \\
\hline 8 & Resick vd. (2009) & & & & & & & & $\star$ & \\
\hline 9 & Ham vd. (2017) & & & & & & & & $\star$ & \\
\hline 10 & Ham vd. (2018) & & & & & & & & $\star$ & \\
\hline 11 & $\begin{array}{l}\text { O'Reilly III vd. } \\
\text { (2014) }\end{array}$ & & & $\star$ & & & & & $\star$ & \\
\hline 12 & $\begin{array}{l}\text { O'Reilly III vd. } \\
\text { (2018) } \\
\end{array}$ & & & $\star$ & & & $\star$ & & $\star$ & \\
\hline 13 & $\begin{array}{l}\text { Petrenko vd. } \\
\text { (2016) }\end{array}$ & $\star$ & $\star$ & & $\star$ & & & & $\star$ & \\
\hline 14 & Aabo vd. (2019) & & $\star$ & & & & & & & \\
\hline 15 & $\begin{array}{l}\text { Bassyouny vd. } \\
(2020)\end{array}$ & $\star$ & & & & & & & & \\
\hline 16 & Fung vd. (2020) & $\star$ & $\star$ & $\star$ & & & & & & \\
\hline 17 & $\begin{array}{l}\text { Buchholz vd. } \\
(2018)\end{array}$ & $\star$ & $\star$ & $\star$ & $\star$ & $\star$ & & & & \\
\hline 18 & $\begin{array}{l}\text { Koch-Bayram ve } \\
\text { Biemann (2020) }\end{array}$ & & & & & & & $\star$ & & \\
\hline 19 & Kontesa vd. (2020) & & & & & & & $\star$ & & \\
\hline 20 & Buyl vd. (2019) & & & & & & & & & $\star$ \\
\hline
\end{tabular}

Veri kaynağında yer alan 55 makalenin 52'sinin ölçme araçları açısından incelenmesi Tablo 1'de yer almaktadır. Bununla birlikte, 3 çalışmanın (Rijsenbilt ve Commandeur, 2013; Buchholz, Jaeschk, Lopatta ve Maas, 2018; Kim, 2018) Tablo 1'deki ölçüm araçlarından farklı bir metodolojiye sahip olmasından dolayı, söz konusu 3 çalışmanın hangi ölçüm araçlarını kullandığı Tablo 1'den ayrı bir şekilde raporlanması tercih edilmiştir. Rijsenbilt ve Commandeur (2013), CEO narsisizminin ölçülebilmesi için 15 objektif gösterge belirlemiştir (örneğin, kurumsal jet kullanımı, satın alma aktivitelerinin sayısı ve değeri, biyografide kullanılan satır sayısı, CEO ödülleri). Kalan 2 çalışma (Buchholz vd. 2018; Kim, 2018), CEO narsisizmi ölçüm sürecinde Rijsenbilt ve Commandeur (2013) tarafından geliştirilen 15 objektif göstergeden oluşan indeksi temel almıştır. Böylece, 3 çalışmanın Rijsenbilt ve Commandeur (2013) tarafından geliştirilmiş CEO narsisizmi göstergeleri aracılığıyla CEO narsisizmi ölçümlediği tespit edilmiştir. 


\section{Tartışma ve Sonuç}

Çalışma kapsamında CEO narsisizmiyle ilgili ampirik araştırmalar ülke, sektör, dergi, veri kaynakları, ölçüm araçları ve geçerlilik testleri açısından sistematik bir şekilde incelenmiştir.

CEO narsisizmiyle ilgili çalışmaların çoğunluğu ABD firmaları üzerinde çalışmalarını kurgulamışlardır. Avrupa ve Asya bölgesinde yer alan firmalarda çalışan CEO'lardan veri toplayan çalışmalar olsa da bu çalışmaların toplam sayısı azınlıktadır. Sektör açısından CEO narsisizmi araştırmaları genellikle bankacılık sektörü, yazııım sektörü, elektronik endüstrisi, ilaç firmaları, imalat sektörü gibi alanlara odaklanmaktadır. Sektör ve ülke açısından ön plana çıkan bir özellik de Fortune 500/1000 ve S\&P 500/1000 firmalarının CEO'larından veri toplanmasıdır. CEO narsisizmiyle ilgili çalışmaların bir kısmı bu listede yer alan ABD firmalarını özellikle seçmişken, bir kısmı ise ülke açısından farklılığa gitmemiştir.

Ülke açısından çalışmaların çoğunlukla ABD firmalarında faaliyet gösteren CEO'lardan oluşması, çalışmaların ABD dışında faaliyet gösteren firmaların CEO'larına yönelik genelleştirilebilmesi açısından bir sınırılık oluşturmaktadır. Farklı kültürlerde ve coğrafyalarda faaliyet gösteren firmaların CEO'larının narsistik eğilimlerinin örgütsel çıktılar üzerindeki etkisi kapsamında ilginç sonuçlar ortaya çıkarabilir. Sektör açısından ise, sıradışı bağlamlara yönelik yapılan genel çağrıyı dikkate almak faydalı olabilir (Bamberger, 2010). CEO narsisizmi araştırmalarında, eğitim, sağlık, hukuk ve kâr amacı gütmeyen firmalar, sektörel açıdan neredeyse tamamen dikkate alınmamış sektörlere işaret etmektedir. Ayrıca, CEO narsisizm araştırmalarının özellikle Fortune ve S\&P listelerinde yer alan firmalara yönelik büyük oranda çalışmalar yapması, CEO narsisizmi araştırmalarının bulgularının küçük ve orta ölçekteki firmalara genellenmesini zorlaştırmaktadır. Aile işletmelerinin üst düzey yöneticilerini gündeme alan herhangi bir çalışmaya da rastlanılamamıştır. Bu bağlamda, gelecek araştırmaların sıradışı bağlamlara, ABD dışında faaliyet gösteren firmalara, gelişmekte olan ülkelerin firmalarına, küçük ve orta ölçekli firmalara odaklanması CEO narsisizmi araştırmaları açısından bir zenginlik olabilir.

CEO narsisizmiyle ilgili Türkiye'de yapılan herhangi bir çalışmaya rastlanılamamıştır. Araştırma alanının yeni gelişmekte olması ve Türkçe alan yazınında CEO narsisizmi konusunda herhangi bir çalışmaya rastlanılamamış olması konunun Türkiye örnekleminde gündeme gelmeme sebeplerinden olabilir. Ayrıca, CEO narsisizminin ölçüm sürecinde birbirinden oldukça farklı ölçme araçlarının kullanılmış olması konunun anlamlandırımasını zorlaştırmış olabilir. Çalışmanın giriş kısmında da belirtildiği üzere, aynı ölçüm aracının bile birbirinden farklı kullanımlarına rastlanılmaktadır. CEO narsisizminin ölçüm sürecini doğrudan ele alan yeterli çalışmanın da olmayışı, alanda çalışmak isteyen araştırmacılar için bir engel olabilir. CEO narsisizmi çalışmalarında yoğun bir şekilde kullanılan örtük ölçüm yöntemlerinin doğası da yönetim alanında çalışan araştırmacılar için alışılmadık görülmüş olabilir. Bu bağlamda, söz konusu çalışma kapsamında CEO narsisizm araştırmalarının ölçüm sürecinin aydınlatılmasına mütevazı anlamda katkı sağlanması hedeflenmiştir.

CEO narsisizmi araştırmaları çoğunlukla işletme alanındaki dergilerde yayınlanırken, ekonomi ve finans alanındaki dergilerde de kendisine yer bulmaktadır. CEO narsisizmi ilginç ve yeni bir konu olduğu için alanın önde gelen saygın dergilerinde yayın potansiyeli bulunmaktadır. Veri kaynağı açısından, ölçüm aracı olarak CEO narsisizmi indeksini kullanan araştırmaların kullandıkları arşiv verisinin çoğunlukla benzer kaynaklardan faydalandığı görülmektedir. Üçüncü taraf değerlendirmelerini ölçüm aracı olarak kullanan çalışmalar ise, psikoloji alanında uzman doktora öğrencileri, firma çalışanları üzerinden hedef firmanın CEO'su hakkında veri topladığı görülmektedir. Psikometrik öz-raporlama araçlarını kullanan çalışmalar ise, verileri doğrudan CEO'lar üzerinden toplamaktadır.

CEO narsisizmi araştırmaları çoğunlukla CEO narsisizmi indeksinden yararlanmaktadır. Bununla birlikte, CEO narsisizmi indeksinden yararlanan çalışmaların indeksin kullanımında ortak bir anlayışa sahip olmadığı görülmektedir. Çünkü indeksin orijinal halinde geliştirilmiş 5 maddelik gösterge formunun çeşitli göstergeleri çıkarılarak CEO narsisizmi araştırmalarının tasarlandığı görülmektedir. Arşiv verilerinden faydalanarak CEO'ların narsistik eğilimlerini ölçen araştırmalar sadece CEO narsisizmi indeksinden yararlanmamaktadır. Arşiv verisi kapsamında, CEO'ların imzaları ve üçüncü taraf değerlendirmeleri aracılığıyla CEO narsisizminin ölçümünü gerçekleştiren çalışmalar da vardır. Bazı çalışmaların arşiv verisi 
kapsamında hem CEO narsisizmi indeksi göstergelerinden hem de CEO imza büyüklüğü aracından yararlandığı görülmektedir.

CEO narsisizmini arşiv verisi aracılığıyla ölçen çalışmalar (CEO narsisizmi indeksi, CEO'ların imza büyüklüğü, üçüncü taraf değerlendirmeleri), CEO’ların narsistik eğilimlerini zamansal olarak değişmez olarak kabul etmektedir. Diğer bir deyişle, CEO'ların narsistik eğilimleri zamandan ve bağlamdan bağımsız bir şekilde genel ve değişmez bir kişilik özelliği olarak görülmektedir. Ayrıca, CEO narsisizmini psikometrik öz-raporlama ya da ölçek aracılığıyla ölçümleyen çalışmalar da CEO'ların narsistik eğilimini tek bir seferde ölçümlemiş, genel ve değişmez bir kişilik özelliği olarak değerlendirmiştir. Bu anlamda, CEO'ların narsistik eğilimini zamana ve bağlama göre değişen bir şekilde ele alan çalışmaya rastlanılmamıştır.

CEO narsisizmi araştırmalarının üst düzey yöneticilerin narsistik eğilimlerini zaman ve bağlamsal açıdan değişmez olarak kabul etmesine rağmen, kişilik psikolojisi ve sosyal psikoloji alanındaki güncel araştırmalar bireylerin narsistik eğilimlerinin zaman ve bağlamdan bağımsız olmadığını, farklı zaman ve bağlam durumlarında bireylerin narsistik eğilimlerinin değişkenlik gösterebildiğini vurgular. Örneğin, toplumsal odağı ve empatisi zaman içerisinde iyileşerek değişkenlik gösteren bireylerin, narsistik eğilimlerinin azaldığı bulunmuştur (Giacomin ve Jordan, 2014). Narsisizmin zamansal ve durumsal açıdan farklılık gösterip göstermediğini araştırmak üzere gerçekleştirilen çalışmada ise, "günlük metodolojisi" aracılığıyla 10 günlük zaman diliminde bireylerin her gün narsisizm eğilimi ölçülmüştür. Narsisizmi süreç içerisinde değişen bir kavram olarak ele alan çalışmada, narsisizmin kısa zaman dilimlerinde bile dalgalandığı ve birey içi değişkenlik gösteren bir eğilim olduğu bulunmuştur (Giacomin ve Jordan, 2016a). Bir başka çalışmada ise "günlük metodolojisi" benimsenerek 14 gün boyunca narsistik eğilimin her gün değişkenlik gösterip göstermediği araştırılmış, narsisizmin zaman içerisinde değişkenlik gösterdiği bulunmuştur (Giacomin ve Jordan, 2016b). Bu bağlamda, gelecek CEO narsisizmi araştırmalarının narsisizmin farklı zaman ve bağlamlarda değişkenlik gösterebildiğine dair psikoloji literatürünü dikkate alması alana bir zenginlik katabilir. CEO'ların narsistik eğilimlerinin zaman içerisinde değişebildiğini benimseyen çalışmalar CEO narsisizmiyle ilgili boylamsal çalışmalar gerçekleştirebilir. Böylece, CEO narsisizmiyle ilgili nedensel bir araştırma tasarımı gerçekleştirilebilir.

CEO narsisizmi indeksinin göstergelerinin üst düzey yöneticilerin narsistik eğilimlerini ne kadar yansıttığı ve temsil ettiği güncel çalışmalar tarafından sorgulanmaktadır (Carey vd., 2015; Koch-Bayram ve Biemann, 2020; van Scotter, 2020). Bu bağlamda, CEO narsisizmi indeksi veya arşiv verisi kullanan çalışmalarda ilave geçerlilik hesaplamalarının (örneğin, kavramsal geçerlilik) yapılması gerektiği vurgulanmaktadır. Çalışma kapsamında, CEO narsisizmi araştırmalarının ilave ya da destekleyici geçerlilik hesaplamaları yapıp yapmadığı incelenmiştir. CEO narsisizmi indeksini kullanan toplam 32 çalışmadan sadece 10 çalışmanın ilave geçerlilik analizi yaptığı tespit edilmiştir. Üçüncü taraf değerlendirmeleri kapsamında CEO'ların narsistik eğilimini değerlendiren 9 çalışmadan 7 çalışmanın ilave geçerlilik analizi yaptığı görülmektedir. 3 çalışmanın da arşiv verisi kapsamında ilave geçerlilik analizi yaptığı görülmektedir. Böylece veri kaynağında incelenen 55 çalışmadan 20 çalışmanın ilave geçerlilik analizi yaptığı görülmektedir. Bu bağlamda, çalışma sonuçlarına göre CEO narsisizmi indeksini kullanan çalışmaların ilave geçerlilik analizlerini düşük düzeyde yaptığı, üçüncü taraf değerlendirmeleri aracılığıyla ölçüm yapan çalışmaların ise büyük oranda ilave geçerlilik analizleri yaptığı bulunmuştur. Gelecek araştırmacılar CEO narsisizmi indeksini kullanırken ilave geçerlilik analizlerini ihmal etmemeleri gerekmektedir. Özellikle alanın saygın dergileri CEO narsisizmi indeksi kullanımında ilave geçerlik analizi süreçlerini önemsemektedir.

CEO'lardan doğrudan psikolojik öz-raporlama ya da ölçek aracıyla veri toplamanın zorluğundan dolayı çok az sayıda çalışma ölçek aracılığıyla ölçüm sürecini gerçekleştirmiştir. Ölçek kullanan mevcut çalışmalar ise CEO narsisizminin çok boyutlu doğasını dikkate alan kavramsallaştırmaları dikkate almamıştır. Gelecek CEO narsisizmi araştırmaları, Back vd. (2013)'nin çalışmasında geliştirdiği narsisizmin hayranlık ve rekabetten oluşan iki boyutlu doğasını dikkate alarak araştırmalarını tasarlayabilir. Bu ölçek narsisizmin çok boyutlu doğasını dikkate alarak, CEO narsisizminin örgütsel çıktılar üzerindeki etkisini farklılaştırabilir. Böylece, CEO narsisizm araştırmalarında birbiriyle tutarsız sonuçlar üretilmesinin önüne geçilebilir. Son olarak, CEO narsisizmi araştırmalarında ölçek kullanımını tercih eden çalışmaların normallik varsayımlarına dikkat etmesi daha sağlıklı sonuçların elde edilmesine katkı sağlayabilir (Şencan ve Fidan, 2020). 
CEO narsisizmi araştırmalarının metodolojik bölümlerinin incelenmesi sürecinde, tek bir nitel çalışmaya rastlanılmamıştır. Bu anlamda niçin bazı üst düzey yöneticilerin diğer yöneticilere göre daha narsist eğilimlere sahip olduğu, bu narsist eğilimlerin nelere yol açtığı ve hangi faktörlerin bu narsist eğilimlerin yol açtıkları üzerinde düzenleyici rolü olduğuna yönelik derinlemesine görüşmeler gerçekleştirilebilir.

CEO narsisizmi araştırmalarında ön plana çıkan ölçüm araçları CEO narsisizmi indeksi, CEO imza büyüklüğü, ölçek, üçüncü taraf değerlendirmeleri olmasına rağmen, arşiv verisi kapsamında farklı yöntemlerden istifade edilebilir. Bu bağlamda, takım narsisizmi çalışması kapsamında kullanılmış olan "twitter analizi" (Grijalva, Maynes, Badura ve Whiting, 2020), CEO narsisizmi araştırmalarında kullanılabilir. Ayrıca, örgütsel çalışmalarda sıradışı yöntemlere yönelik çağrı kapsamında (Bansal ve Corley, 2011), "otobiyografi yöntemi" aracılı̆ııla (Mathias ve Smith, 2016), CEO'ların otobiyografisi de CEO'ların narsistik eğilimlerini değerlendirmede kullanılabilir. Bununla birlikte, bu süreçlerde dikkat edilmesi gereken bu araçların ilave geçerlilik analizlerinin gerçekleştirilmesidir.

\section{Beyan ve Açıklamalar (Declarations and Disclosures)}

Yazarların Etik Sorumlulukları (Ethical Responsibilities of Authors): Bu çalışmanın yazarları, araştırma ve yayın etiği ilkelerine uyduklarını kabul etmektedirler.

Çıkar Çatışması (Conflicts of Interest): Yazarlar tarafından herhangi bir çıkar çatışması beyan edilmemiştir.

Finansal Destek (Funding): Yazarlar, çalışmanın hazırlanması ve/veya yayınlanması sürecinde herhangi bir finansal destek almamışlardır.

Yazar Katkı Oranı (Author Contributions): Yazarlar, çalışmaya olan katkılarını şu şekilde beyan etmişlerdir: Kavramlaştırma ve çalışma dizaynı, H. Keskin ve S. Ş. Fidan; verilerin toplanması, H. Keskin ve S. Ş. Fidan; verilerin analizi ve sonuçların yorumlanması, H. Keskin ve S. Ş. Fidan; çalışmanın ilk/taslak halinin yazılması, H. Keskin ve S. Ş. Fidan; çalışmanın gözden geçirilmesi ve düzenlenmesi/düzeltilmesi, H. Keskin ve S. Ş. Fidan. Çalışmanın ilk ve son hali tüm yazarlar tarafından okunmuş ve onaylanmış olup, yazarlar çalışmalarıyla ilgili sorumluluğu kabul etmektedirler.

intihal Denetimi (Plagiarism Checking): Bu çalışma, intihal tarama programı kullanılarak intihal taramasından geçirilmiştir.

\section{Son Notlar}

1. Uluslararası yazında açılımı "Chief Executive Officer" olan CEO terimini tam olarak karşılayan Türkçe kelime bulunmamaktadır. CEO, firmalarda stratejik kararların oluşturulmasından ve uygulanmasından sorumlu olan en üst düzeydeki yöneticidir.

\section{Kaynaklar}

Aabo, T., \& Eriksen, N. B. (2017). Corporate risk and the humpback of CEO narcissism. Review of Behavioral Finance, 10(3), 252-273.

Aabo, T., Hoejland, F., \& Pedersen, J. (2019). Do narcissistic CEOs rock the boat? Review of Behavioral Finance. Forthcoming.

Aabo, T., Als, M., Thomsen, L., \& Wulff, J. N. (2020). Watch me go big: CEO narcissism and corporate acquisitions. Review of Behavioral Finance. Ahead-of-print.

Ahn, J. S., Assaf, A. G., Josiassen, A., Baker, M. A., Lee, S., Kock, F., \& Tsionas, M. G. (2020). Narcissistic CEOs and corporate social responsibility: Does the role of an outside board of directors matter? International Journal of Hospitality Management, 85, 1-8.

Aktas, N., De Bodt, E., Bollaert, H., \& Roll, R. (2012). CEO narcissism and the takeover process: From private initiation to deal completion. Journal of Financial and Quantitative Analysis, 51(1), 13-137.

Agnihotri, A., \& Bhattacharya, S. (2019). CEO narcissism and internationalization by Indian firms. Management International Review, 59(6), 889-918. 
Al-Shammari, M., Rasheed, A., \& Al-Shammari, H. A. (2019). CEO narcissism and corporate social responsibility: Does CEO narcissism affect CSR focus? Journal of Business Research, 104, 106-117.

Ames, D. R., Rose, P., \& Anderson, C. P. (2006). The NPI-16 as a short measure of narcissism. Journal of Research in Personality, 40(4), 440-450.

Ashton, M. C., Lee, K., \& De Vries, R. E. (2014). The HEXACO honesty-humility, agreeableness, and emotionality factors: A review of research and theory. Personality and Social Psychology Review, 18(2), 139-152.

Back, M. D., Küfner, A. C., Dufner, M., Gerlach, T. M., Rauthmann, J. F., \& Denissen, J. J. (2013). Narcissistic admiration and rivalry: Disentangling the bright and dark sides of narcissism. Journal of Personality and Social Psychology, 105(6), 1013.

Bamberger, P. A., \& Pratt, M. G. (2010). Moving forward by looking back: Reclaiming unconventional research contexts and samples in organizational scholarship. Academy of Management Journal, 53(4), 665-671.

Bassyouny, H., Abdelfattah, T., \& Tao, L. (2020). Beyond narrative disclosure tone: The upper echelons theory perspective. International Review of Financial Analysis, 1-13, 101499.

Bansal, P., \& Corley, K. (2011). The coming of age for qualitative research: Embracing the diversity of qualitative methods. Academy of Management Journal, 54(2), 233-237.

Bianchi, E. C. (2014). Entering adulthood in a recession tempers later narcissism. Psychological Science, 25(7), 14291437.

Buchholz, F., Jaeschke, R., Lopatta, K., \& Maas, K. (2018). The use of optimistic tone by narcissistic CEOs. Accounting, Auditing \& Accountability Journal, 31(2), 531-562.

Buyl, T., Boone, C., \& Wade, J. B. (2019). CEO narcissism, risk-taking, and resilience: An empirical analysis in US commercial banks. Journal of Management, 45(4), 1372-1400.

Carey, A. L., Brucks, M. S., Küfner, A. C., Holtzman, N. S., Back, M. D., Donnellan, M. B., Mehl, M. R. (2015). Narcissism and the use of personal pronouns revisited. Journal of Personality and Social Psychology, 109(3), 1-15.

Capalbo, F., Frino, A., Lim, M. Y., Mollica, V., \& Palumbo, R. (2018). The impact of CEO narcissism on earnings management. Abacus, 54(2), 210-226.

Chatterjee, A., \& Hambrick, D. C. (2007). It's all about me: Narcissistic chief executive officers and their effects on company strategy and performance. Administrative Science Quarterly, 52(3), 351-386.

Chatterjee, A., \& Hambrick, D. C. (2011). Executive personality, capability cues, and risk taking: How narcissistic CEOs react to their successes and stumbles. Administrative Science Quarterly, 56(2), 202-237.

Cheshure, A., Zeigler-Hill, V., Sauls, D., Vrabel, J. K., \& Lehtman, M. J. (2020). Narcissism and emotion dysregulation: Narcissistic admiration and narcissistic rivalry have divergent associations with emotion regulation difficulties. Personality and Individual Differences, 154, 1-5.

Chen, J., Zhang, Z., \& Jia, M. (2019). How CEO narcissism affects corporate social responsibility choice? Asia Pacific Journal of Management, 1-28.

Cragun, O. R., Olsen, K. J., \& Wright, P. M. (2020). Making CEO narcissism research great: A review and meta-analysis of CEO narcissism. Journal of Management, 46(6), 908-936.

Cycyota, C. S., \& Harrison, D. A. (2006). What (not) to expect when surveying executives: A meta-analysis of top manager response rates and techniques over time. Organizational Research Methods, 9(2), 133-160.

Emmons, R. A. (1987). Narcissism: Theory and measurement. Journal of Personality and Social Psychology, $52(1), 11$.

Engelen, A., Neumann, C., \& Schmidt, S. (2016). Should entrepreneurially oriented firms have narcissistic CEOs? Journal of Management, 42(3), 698-721.

Fehn, T., \& Schütz, A. (2020). What you get is what you see: Other-rated but not self-rated leaders' narcissistic rivalry affects followers negatively. Journal of Business Ethics, 1-18.

Fung, H. G., Qiao, P., Yau, J., \& Zeng, Y. (2020). Leader narcissism and outward foreign direct investment: Evidence from Chinese firms. International Business Review, 29(1), 1-11.

Gerstner, W. C., König, A., Enders, A., \& Hambrick, D. C. (2013). CEO narcissism, audience engagement, and organizational adoption of technological discontinuities. Administrative Science Quarterly, 58(2), $257-291$.

Giacomin, M., \& Jordan, C. H. (2014). Down-regulating narcissistic tendencies: Communal focus reduces state narcissism. Personality and Social Psychology Bulletin, 40(4), 488-500.

Giacomin, M., \& Jordan, C. H. (2016a). The wax and wane of narcissism: Grandiose narcissism as a process or state. Journal of Personality, 84(2), 154-164. 
Giacomin, M., \& Jordan, C. H. (2016b). Self-focused and feeling fine: Assessing state narcissism and its relation to wellbeing. Journal of Research in Personality, 63, 12-21.

Gosling, S. D., Rentfrow, P. J., \& Swann Jr, W. B. (2003). A very brief measure of the Big-Five personality domains. Journal of Research in Personality, 37(6), 504-528.

Grijalva, E., Maynes, T. D., Badura, K. L., \& Whiting, S. W. (2020). Examining the "I" in team: A longitudinal investigation of the influence of team narcissism composition on team outcomes in the NBA. Academy of Management Journal, 63(1), 7-33.

Gupta, A., \& Misangyi, V. F. (2018). Follow the leader (or not): The influence of peer CEOs' characteristics on interorganizational imitation. Strategic Management Journal, 39(5), 1437-1472.

Gupta, A., Nadkarni, S., \& Mariam, M. (2019). Dispositional sources of managerial discretion: CEO ideology, CEO personality, and firm strategies. Administrative Science Quarterly, 64(4), 855-893.

Ham, C., Lang, M., Seybert, N., \& Wang, S. (2017). CFO narcissism and financial reporting quality. Journal of Accounting Research, 55(5), 1089-1135.

Ham, C., Seybert, N., \& Wang, S. (2018). Narcissism is a bad sign: CEO signature size, investment, and performance. Review of Accounting Studies, 23(1), 234-264.

Hendin, H. M., \& Cheek, J. M. (1997). Assessing hypersensitive narcissism: A reexamination of Murray's Narcism Scale. Journal of Research in Personality, 31(4), 588-599.

Huang, X., Chen, H., Wang, L., \& Zeng, S. (2019). How does leader narcissism influence firm internationalization? IEEE Transactions on Engineering Management, 67(3), 683-696.

Ingersoll, A. R., Glass, C., Cook, A., \& Olsen, K. J. (2019). Power, status and expectations: How narcissism manifests among women CEOs. Journal of Business Ethics, 158(4), 893-907.

Judd, J. S., Olsen, K. J., \& Stekelberg, J. (2017). How do auditors respond to CEO narcissism? Evidence from external audit fees. Accounting Horizons, 31(4), 33-52.

Kashmiri, S., Nicol, C. D., \& Arora, S. (2017). Me, myself, and I: influence of CEO narcissism on firms' innovation strategy and the likelihood of product-harm crises. Journal of the Academy of Marketing Science, 45(5), 633-656.

Kim, B., Lee, S., \& Kang, K. H. (2018). The moderating role of CEO narcissism on the relationship between uncertainty avoidance and CSR. Tourism Management, 67, 203-213.

Kim, B. H. (2018). Is narcissism sustainable in CEO leadership of state-owned enterprises? Sustainability, 10(7), 2425.

Koch-Bayram, I. F., \& Biemann, T. (2020). Signs of narcissism? Reconsidering a widely used measure. Journal of Leadership \& Organizational Studies, 27(4), 389-405.

Kontesa, M., Brahmana, R., \& Tong, A. H. H. (2020). Narcissistic CEOs and their earnings management. Journal of Management and Governance, 1-27.

Lin, H., Sui, Y., Ma, H., Wang, L., \& Zeng, S. (2018). CEO narcissism, public concern, and megaproject social responsibility: Moderated mediating examination. Journal of Management in Engineering, 34(4), 1-10.

Lin, F., Lin, S. W., \& Fang, W.-C. (2020). How CEO narcissism affects earnings management behaviors. The North American Journal of Economics and Finance, 51, 1-12.

Liu, Y., Li, Y., Hao, X., \& Zhang, Y. (2019). Narcissism and learning from entrepreneurial failure. Journal of Business Venturing, 34(3), 496-512.

Mahmood, F., Qadeer, F., Sattar, U., Ariza-Montes, A., Saleem, M., \& Aman, J. (2020). Corporate social responsibility and firms' financial performance: A new insight. Sustainability, 12(10), 4211.

Marquez-Illescas, G., Zebedee, A. A., \& Zhou, L. (2019). Hear me write: Does CEO narcissism affect disclosure? Journal of Business Ethics, 159(2), 401-417.

Mathias, B. D., \& Smith, A. D. (2016). Autobiographies in organizational research: Using leaders' life stories in a triangulated research design. Organizational Research Methods, 19(2), 204-230.

Manley, H., Paisarnsrisomsuk, N., \& Roberts, R. (2020). The effect of narcissistic admiration and rivalry on speaking performance. Personality and Individual Differences, 154, 109624.

Oesterle, M. J., Elosge, C., \& Elosge, L. (2016). Me, myself and I: The role of CEO narcissism in internationalization decisions. International Business Review, 25(5), 1114-1123.

Olsen, K. J., \& Stekelberg, J. (2016). CEO narcissism and corporate tax sheltering. The Journal of the American Taxation Association, 38(1), 1-22. 
O'Reilly III, C. A., Doerr, B., Caldwell, D. F., \& Chatman, J. A. (2014). Narcissistic CEOs and executive compensation. The Leadership Quarterly, 25(2), 218-231.

O'Reilly III, C. A., Doerr, B., \& Chatman, J. A. (2018). "See you in court": How CEO narcissism increases firms' vulnerability to lawsuits. The Leadership Quarterly, 29(3), 365-378.

Patel, P. C., \& Cooper, D. (2014). The harder they fall, the faster they rise: Approach and avoidance focus in narcissistic CEOs. Strategic Management Journal, 35(10), 1528- 1540.

Peterson, S. J., Galvin, B. M., \& Lange, D. (2012). CEO servant leadership: Exploring executive characteristics and firm performance. Personnel Psychology, 65(3), 565-596.

Petrenko, O. V., Aime, F., Ridge, J., \& Hill, A. (2016). Corporate social responsibility or CEO narcissism? CSR motivations and organizational performance. Strategic Management Journal, 37(2), 262-279.

Raskin, R., \& Terry, H. (1988). A principal-components analysis of the Narcissistic Personality Inventory and further evidence of its construct validity. Journal of Personality and Social Psychology, 54(5), 890-902.

Reina, C. S., Zhang, Z., \& Peterson, S. J. (2014). CEO grandiose narcissism and firm performance: The role of organizational identification. The Leadership Quarterly, 25(5), 958-971.

Resick, C. J., Whitman, D. S., Weingarden, S. M., \& Hiller, N. J. (2009). The bright-side and the dark-side of CEO personality: examining core self-evaluations, narcissism, transformational leadership, and strategic influence. Journal of Applied Psychology, 94(6), 1365-1381.

Rijsenbilt, A., \& Commandeur, H. (2013). Narcissus enters the courtroom: CEO narcissism and fraud. Journal of Business Ethics, 117(2), 413-429.

Rogoza, R., Wyszyńska, P., Maćkiewicz, M., \& Cieciuch, J. (2016). Differentiation of the two narcissistic faces in their relations to personality traits and basic values. Personality and Individual Differences, 95, 85-88.

Rudman, L. A., Dohn, M. C., \& Fairchild, K. (2007). Implicit self-esteem compensation: automatic threat defense. Journal of Personality and Social Psychology, 93(5), 798.

Rudolph, C. W., Murphy, L. D., \& Zacher, H. (2020). A systematic review and critique of research on "healthy leadership". The Leadership Quarterly, 31(1), 101335.

Samuel, D. B., \& Widiger, T. A. (2008). Convergence of narcissism measures from the perspective of general personality functioning. Assessment, 15(3), 364-374.

Seifzadeh, M., Salehi, M., Abedini, B., \& Ranjbar, M. H. (2020). The relationship between management characteristics and financial statement readability. EuroMed Journal of Business, 16(1), 108-126.

Shabbir, A., \& Kousar, S. (2019). Impact of founder CEO and CEO ownership on entrepreneurial orientation, moderating role of CEO narcissism. Asia Pacific Journal of Innovation and Entrepreneurship, 13(2), 153-167.

She, Z., Li, Q., London, M., Yang, B., \& Yang, B. (2019). Effects of CEO narcissism on decision-making comprehensiveness and speed. Journal of Managerial Psychology, 35(1), 42-55.

Short, J. C., Broberg, J. C., Cogliser, C. C., \& Brigham, K. H. 2010. Construct validation using computer aided text analysis. Organizational Research Methods, 13(2), 320-347.

Şencan, H., \& Fidan, Y. (2020). Likert verilerinin kullanıldığı keşfedici faktör analizlerinde normallik varsayımı ve faktör çıkarma üzerindeki etkisinin SPSS, Factor ve Prelis yazılımlarıyla sınanması. Business \& Management Studies: An International Journal, 8(1), 640-687.

Tang, Y., Mack, D. Z., \& Chen, G. (2018). The differential effects of CEO narcissism and hubris on corporate social responsibility. Strategic Management Journal, 39(5), 1370- 1387.

Thielmann, I., Spadaro, G., \& Balliet, D. (2020). Personality and prosocial behavior: A theoretical framework and metaanalysis. Psychological Bulletin, 146(1), 30-90.

Twenge, J. M., \& Foster, J. D. (2008). Mapping the scale of the narcissism epidemic: Increases in narcissism 2002-2007 within ethnic groups. Journal of Research in Personality, 42(6), 1619-1622.

Uppal, N. (2020). CEO narcissism, CEO duality, TMT agreeableness and firm performance. European Business Review, 32(4), 573-590.

Van Scotter, J. R. (2020). Narcissism in CEO research: A review and replication of the archival approach. Management Review Quarterly, 70(4), 629-674.

Wales, W. J., Patel, P. C., \& Lumpkin, G. T. (2013). In pursuit of greatness: CEO narcissism, entrepreneurial orientation, and firm performance variance. Journal of Management Studies, 50(6), 1041-1069. 
Yook, K. H., \& Lee, S. Y. (2020). Chief executive officer narcissism and firm value: The mediating role of corporate social responsibility in the South Korean context. Corporate Social Responsibility and Environmental Management, 27(4), 1709-1718.

Zhang, H., Ou, A. Y., Tsui, A. S., \& Wang, H. (2017). CEO humility, narcissism and firm innovation: A paradox perspective on CEO traits. The Leadership Quarterly, 28(5), 585-604.

Zhu, D. H., \& Chen, G. (2015). CEO narcissism and the impact of prior board experience on corporate strategy. Administrative Science Quarterly, 60(1), 31-65.

Zhu, D. H., \& Chen, G. (2015b). Narcissism, director selection, and risk-taking spending. Strategic Management Journal, 36(13), 2075-2098. 
This Page Intentionally Left Blank 